\title{
日本の医療が抱える問題に対して 学会専門医・認定医が果たす役割は?
}

\section{山田隆司}

\section{はじめに}

現在の日本の医療の問題といえば，増え続ける医療 費，医師不足ということになろうか。医療費について は高度先端医療に関わる問題もさることながら，高齢 者の医療費の問題は中でも中心的課題だ。また医療崩 壊の直接的原因と言われている医師不足は, 地域住民 にとって最も深刻な問題となっている．高齢者の医療 費, 医師数共に量的な問題だが，それでは財源確保， 医師確保が満たされれば問題解決につながるかという と，決してそうではない。声高に医療費の拡大，医師 数の増加を叫び続ければ良いという問題ではない。限 りある医療資源の中で最大限に有効活用することが今 求められている。いわば量から質の問題に日本の医療 は今直面しているのである.

\section{1. 高齢者医療について}

高齢化が進めば進むほど，平均寿命が延びれば延び るほど,一人当たりの健康問題は増え, 治療対象とな る疾患が当然増える。交通事故や，突然の血管系のイ ベントで亡くなる以外は癌も含め, 加齢とともに人は 徐々に衰弱し，死へと向かっていくことは避けられな い,むしろ生命体としてごく自然な成り行きである. 終末期に近い後期高歯者に対して，心停止の瞬間まで いわゆる標準的な治療をし続けることが果たして適切 なのか, 医療現場では戸惑いがみられている。一方で 在宅医療の推進が叫ばれ, 終末期を自宅で迎える人も 一定の割合でみられるようになってきた，彼らは在宅 でできうる，きわめて制限された医療環境の中でそれ を甘受し生を全うする。しかし時として在宅で死を迎 えることこそ, 患者家族の満足度が高いことが指摘さ
れている。

高齢者医療に関しては殊更に医療の提供に終始する のではなく，介護や家族の関わりといったことが重要 な要素になっているようだ。一般成人と同じ標準的治 療は時として, 高齢者にとってむしろ過剰な介入であ り，そういった不適切な状態がただやみくもに継続さ れている事例もまれではない。

高齢者にとって質の高い医療とは何か？それは分化 された専門的医療を保証することではなさそうだ。一 定の基準があるわけではなく，むしろ個々の高齢者に とって最適な解は高齢者の数だけ存在するといってよ い。その個々の解を見つけうる医師こそ，家庭医であ り総合医，プライマリ・ケア医 (以後家庭医) なのだ。 患者と身近で家族ぐるみで長く付き合い，いつでも， 何でも相談できる，信頼できる医師。そういった医師 こそが高齢者にとって適切なケア提供のカギを握るこ とは間違いない。

\section{2. 医師不足について}

医師の不足が叫ばれ久しいが，地域の医療崩壊と直 接結びついている医師不足は, 地域の中核病院, 特に 自治体病院や公的病院での医師不足がその中心的問題 である，小児科，産婦人科，内科，外科といった診療 科での医師不足が指摘されているが，先端的医療の提 供が阻害されているわけではなく, 主に一般的な分娩, 小児や成人の一次救急, 高齢者の一般的な入院管理と いったところが影響を受けている.

専門医はそれぞれの専門分野の症例を多く経験する ことでその診療の質を上げようとするが，そういった 傾向から当然臓器別専門医は効率よく症例が集まる,

山田隆司（やまだたかし）

日本プライマリ・ケア連合学会副理事長

台東区立台東病院院長 ( ₹ 111-0031 東京都台東区千束 3 丁目 20 番 1 号 E-mail : yamada@jadecom.or.jp) 
より大きな医療機関を志向することになる，専門外の 症例は彼らにとって障害ととらえられがちで，一般的 で幅広い疾患をカバーずることは非効率であり，自ず と自らの診療の幅を制限する傾向は否めない。

そんな専門医にとって，時として一次も含めて救急 も受け入れ，日常的なありふれた疾病管理に終始しな ければならない地域の病院は, 過重な労働を強いられ る割に，専門医としての評価が高くない，割の合わな い病院なのだ。そういった意味から専門医の派遣に頼 らざるを得ない地域の病院にとって, 現行の専門医の 研修システムは医師確保という観点からみて障害と なっている宿命的課題でもある。医師の卒後研修がそ ういった㵴器別専門医を専ら生み出寸研修である限 り, 医師数が単に増えても偏在の傾向はさらに強まる ことが予想され，地域病院の医師不足という問題の解 消にはなかなか繋がらないだろう。

\section{3. 家庭医の専門制・認定制の意義}

現在の日本が抱える医療の問題は, いわば高度先端 医療の提供を最優先し，専門医の育成を中心的に行っ てきた日本の医師養成システムの結果ともいえよう。 地域住民の多様な医療ニーズに応えうる, 幅広い診療 能力をもった家庭医の養成が望まれるところだが，そ ういった地域ニーズにそって医師が養成されてきたか というと，現状では専門医を取得した医師数をみても わかるとおり，必ずしも国民の医療ニーズに沿ったも のとなっていないことは明らかだ.

こういった状況で生まれてきた家庭医の養成につい ては, 殊更地域全体の医療ニーズに応えうるものでな くてはならない，その育成の主たる場所は，地域全体 のニーズが集約する地域の病院を活用すべきである. そういった地域病院での病院総合医としての研修が家 庭医を育成の基盤になるべきであろう。

そういった視点から，家庭医を養成するシステムは 直接地域の医療崩壊の原因となっている地域病院の医 師確保にもつながってくる．研修の質を担保するため に指導体制が万全でない地域は研修には不適切だと いった声も聞かれるが，家庭医を育成することが，現 行の医療問題に直接手を差し伸べるものでない限り,
日本での家庭医の専門制の確立はあり得ないといって も過言ではないだろう。そんな公益的な視点が家庭医 養成, 今後のプライマリ・ケア連合学会の活動には重 要と思われる。

また新しく養成する家庭医の質を保証することも大 切だが, 既存の開業医師が指導医として育成に関わり, 彼らの診療の質を同時に保証し高名いくこともあわ せて重要である. 地域病院での研修とあわせて, 各地 域の医師会と連携し, 在宅医療や予防活動の研修老行 うことが勧められる。 そういった研修が個々の開業医 師にとっての生涯学習となり, かつ日常診療の手助け となることが期待される. 家庭医の育成が既存の開業 医師と相対峙するものではなく, むしろ現在の地域の 一次医療を支えている開業医師こそが育てる母体とな らなければ日本の家庭医は育たない。

\section{おわりに}

本当に質の高い医療とは何か? 単に医療者の提供す るサービスが医療技術的に保証されているのではな く, 医療サービスの受給者の視点からの評価が欠かせ ない. EBMに則った科学的有効性が検証されている といったサービス提供者からみた質だけではなく， 個々の患者の人生にとって有益であるかどうかという 評価こそが本来の医療サービスの質であろう。それに は普段から患者の様々な問題に身近で幅広く対応し， 個別の事情を熟知している医師, 家庭医の存在が欠か せない，個々の患者の弁護士役, 道先案内役ができる 質の高い家庭医，国民から求められる家庭医の育成は 急務なのである。限られた医療資源の中で医療サービ

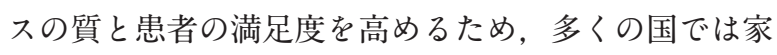
庭医が医療サービスの一定の役割を担っている。しか し家庭医の理念については概悋共通しているものの, 国際基準の家庭医があるわけではない。家庭医である からこそ，それぞれの文化やこれまでのそれぞれの国 の医療システムの経緯から，家庭医はそれぞれの国で 役割も違えば求められる技能も違い, 様々な様相を呈 している，我が国にあった家庭医の育成が今求められ ている。 